\title{
Persistence of VRC01-resistant HIV-1 during antiretroviral therapy
}

\author{
GUO DongXing ${ }^{1 \dagger}$, SHI XuanLing ${ }^{2 \dagger}$, SONG DingKa ${ }^{2} \&$ ZHANG LinQi ${ }^{2 *}$ \\ ${ }^{1}$ Beijing Tropical Medicine Research Institute, Beijing Friendship Hospital, Capital Medical University, Beijing 100050, China; \\ ${ }^{2}$ Comprehensive AIDS Research Center and Research Center for Public Health, School of Medicine, Tsinghua University, Beijing 100084, \\ China
}

Received October 17, 2013; accepted November 22, 2013; published online December 23, 2013

\begin{abstract}
VRC01, a broadly neutralizing monoclonal antibody (bnmAb), can neutralize a diverse array of HIV-1 isolates by mimicking CD4 binding to the envelope glycoprotein gp120. We have previously demonstrated the presence of VRC01-resistant strains in an HIV-1 infected patient during antiretroviral therapy. Here, we report follow-up studies of two subsequent samples from the same patient. With genetic and phenotypic analysis of over 70 full-length molecular clones of the HIV-1 envelope, we show that VRC01-resistant HIV-1 continued to exist and change in its proportion of the infecting virus during treatment with a highly active antiretroviral therapy. Consistent with our previous observation, the resistant phenotype was associated with a single asparagine residue at position 460 (N460), a potential N-linked glycosylation site in the V5 region. The persistence and continuing evolution of VRC01-resistant HIV-1 in vivo presents a great challenge to our future preventative and therapeutic interventions based on VRC01.
\end{abstract}

HIV-1, VRC01, antibody, resistant

Citation: Guo DX, Shi XL, Song DK, Zhang LQ. Persistence of VRC01-resistant HIV-1 during antiretroviral therapy. Sci China Life Sci, 2014, 57: 88-96, doi: 10.1007/s11427-013-4593-y

The entry of human immunodeficiency virus type 1 (HIV-1) into the target cell is dependent on interactions between the viral envelope glycoproteins (gp120 and gp41) and cellular receptor CD4 and coreceptors CCR5 or CXCR4 [1-11]. gp120 contains the CD4-binding site (CD4bs), which although critical for viral entry, is also the viral Achilles' heel for broadly neutralizing monoclonal antibodies (bnmAbs) and polyclonal sera from "elite neutralizers," who display exceptionally strong immune control of viral replication [12-19]. With the recent advent of microculturing and antigen-specific sorting of B cells from "elite neutralizers", researchers have isolated increasing numbers of bnmAbs directed against the CD4bs, including VRC01, VRC03,

$\dagger$ Contributed equally to this work

*Corresponding author (email: zhanglinqi@tsinghua.edu.cn)
3BNC117, 3BNC55, VRC-PG04, and NIH45-46 [12-16, 20,21]. The prototype VRC01, for instance, was isolated from a clade-B-infected individual and neutralized $91 \%$ of a diverse panel of pseudotyped viruses [13]. VRC03, a close relative of VRC01, neutralized about $57 \%$ of these viruses [13]. More recently isolated CD4bs-directed bnmAbs, in particular 3BNC117, 3BNC55, VRC-PG04, and NIH45-46, have shown similar or even higher potency and breadth than the prototype VRC01 [14-16]. Most of these VRC01-like bnmAbs share similar recognition mechanisms, reflected by their convergence on the recognition of the CD4bs on gp120 [17-19]. Their primary mechanism of neutralization must involve blocking the interaction between the virus and receptor CD4 as they compete for the same general area on HIV-1 gp120, although it is worth noting that there may be 
differences in their mechanisms of blocking the gp120-CD4 receptor interaction [12-26].

However, despite the superior potency and breadth of these bnmAbs, each fails to neutralize a small but significant proportion of pseudotyped viruses in each panel. For instance, VRC 01 was unable to neutralize about $10 \%$ of the viruses tested [13], and many of those resistant strains were not derived from "elite neutralizers", such as the donor from which VRC01 was initially isolated. The rise of VRC01resistant viruses in "ordinary" individuals suggests that such variants are either naturally occurring or selected under a VRC01-like antibody response at some point during disease progression. VRC01-resistant strains have also been identified in the VRC01 donor [27]. Only selective archival proviral Env variants remained sensitive, whereas all contemporary plasma-derived variants were resistant, indicating their rapid genetic and phenotypic evolution under strong antibody-based selection pressure [27].

In the course of characterizing diverse HIV-1 strains isolated from infected patients in China, we have identified VRC01-resistant strains derived from CRF08-BC-infected patients [28]. We have also demonstrated that the V5 region, in particular the asparagine residue at position 460 (N460), a potential $\mathrm{N}$-linked glycosylation site (PNGS) in the V5 region, plays a critical role in determining the VRC01resistant phenotype of these strains [29]. In the present study, we determined the in vivo prevalence and evolution patterns of VRC01-resistant variants in vivo. With genetic and phenotypic analysis of over 70 full-length molecular clones of the HIV-1 envelope from blood samples taken from a single, previously investigated patient, we show that VRC01-resistant HIV-1 persisted and evolved in both its proportion and sequence during treatment with a highly active antiretroviral therapy. Consistent with our previous observation, the resistant phenotype was associated with the single asparagine residue at position 460 (N460). The persistence and continuous evolution of VRC01-resistant HIV-1 in vivo imposes a tremendous challenge for preventative and therapeutic interventions based on VRC01.

\section{Materials and methods}

\subsection{Study subject and PCR amplification of full-length gp160 envelope genes}

The study subject is an HIV-1 CRF08_BC-infected intravenous drug user, as reported previously [28]. This patient has received antiretroviral therapy since 2007 and his plasma viral loads were well suppressed (Table 1). His peripheral blood $\mathrm{CD}^{+} \mathrm{T}$ cells increased from 88 cells $\mu \mathrm{L}^{-1}$ on July 26, 2007 to 558 cells $\mu \mathrm{L}^{-1}$ on July 20, 2009 (Table 1). Our initial study was conducted on a sample collected on July 16, 2007 (20070716) and the two samples examined here were collected on January 21 and July 20, 2009 (20090121 and 20090720, respectively), approximately 18
Table 1 Clinical, virological, and immunological characterization of the subject

\begin{tabular}{ccccc}
\hline Sample points & Treatment & $\begin{array}{c}\text { VL } \\
(\text { copies mL }\end{array}$ & $\begin{array}{c}\text { CD4 } \\
\text { counts }\end{array}$ & CD8 counts \\
\hline $2007-7-26$ & AZT+3TC+NVP & $<50$ & 88 & 651 \\
$2007-10-25$ & AZT+3TC+NVP & $<50$ & 377 & 651 \\
$2008-7-25$ & AZT+3TC+NVP & $<50$ & 572 & 1826 \\
$2009-1-21$ & AZT+3TC+NVP & $<50$ & 376 & na \\
$2009-7-20$ & AZT+3TC+NVP & $<50$ & 558 & na \\
\hline
\end{tabular}

and 24 months later (Table 1). This study was approved by the ethic committees of the appropriate institutions [28].

Peripheral blood mononuclear cells (PBMC) were collected and genomic DNA was extracted with the QIAamp DNA Blood Mini Kit (Qiagen, Shanghai, China), according to the manufacturer's protocol. Full-length envelope sequence was amplified with nested PCR with HIV-1 subtype-B'C-specific primers, as previously reported [28]. The PCR product was cloned into the pcDNA ${ }^{\mathrm{TM}} 3.1$ expression vector (Invitrogen, Carlsbad, CA, USA) and verified by sequencing. The full-length gp160 amino acid sequence was analyzed based on a comparison with HIV-1 HXB2.

\subsection{Antibodies and soluble CD4}

IgG-1 VRC01 antibodies were kindly provided by Dr. John Mascola (Vaccine Research Center, National Institute of Allergy and Infectious Diseases, National Institutes of Health, USA). Samples of IgG-1 b12 were obtained from the NIH AIDS Research and Reagents Program. IgG-4 ibalizumab was kindly provided by Dr. David D. Ho (Aaron Diamond AIDS Research Center, The Rockefeller University, USA).

\subsection{Pseudotyped virus production}

The HIV-1 env pseudovirus was generated as described previously [28]. Briefly, 293T cells were cotransfected with the pcDNA ${ }^{\mathrm{TM}} 3.1$ expression vector containing the target $e n v$ gene and the pNL4-3R-E-luciferase viral backbone plasmid in a $1: 3$ ratio. The cell culture medium was replaced with $10 \%$ Dulbecco's modified Eagle's medium containing fetal bovine serum after $4-6 \mathrm{~h}$ and then incubated for an additional $40-48 \mathrm{~h}$ at $37^{\circ} \mathrm{C}$. The pseudotyped viral supernatants were collected after $48 \mathrm{~h}$. The viral titers were quantified by measuring the luciferase activity in relative light units (RLU; Bright-Glo Luciferase Assay System, Promega Biosciences, CA, USA). The supernatants were packaged and stored at $-80^{\circ} \mathrm{C}$.

\subsection{Analysis of viral sensitivity to neutralization}

Neutralization assays were performed as described previously [29]. In brief, 100 TCID $_{50}$ of pseudotyped virus was 
incubated with either serially diluted VRC01, b12, or Ibalizumab for $1 \mathrm{~h}$ at $37^{\circ} \mathrm{C}$ before it was used to inoculate TZM-bl cells (approximately $1.5 \times 10^{4}$ cell/well). Infectivity was quantified as luciferase activity (RLU) $48 \mathrm{~h}$ after infection. Half-maximal inhibitory concentrations $\left(\mathrm{IC}_{50}\right)$ are the concentrations required to inhibit infection by $50 \%$ compared with the control, and were calculated using the dose-response-inhibition model with a variable slope in GraphPad Prism, version 5.0 (GraphPad Software Inc., La Jolla, CA, USA).

\subsection{Sequence and statistical analysis}

Sequences were aligned together with selected subtypes/circulating recombinant forms of geographic importance using the ClustalW program [30]. A phylogenetic analysis was performed with the neighbor-joining method with the Mega package [31]. The reliability of the branching orders was tested by the bootstrap analysis of 1000 replications [32].

\section{Results}

\subsection{Functional cloning of full-length gp160 envelope genes from patient PBMC}

Our laboratory recently characterized the neutralization sensitivity of HIV-1 env clones isolated from chronically infected patients in China [28,29]. We identified two CRF08-BC env clones (CNE47 and CNE48), isolated at a single time point from the same individual, which displayed substantial differences in their sensitivity to VRC01 neutralization. To study the potential persistence of these variants, we collected two subsequent PBMC samples, approximately 18 and 24 months later, from this individual. The full-length gp160 env genes were PCR amplified and cloned directly into a eukaryotic expression vector. A total of 52 and 43 isolates were successfully cloned from sample 20090121 and 20090720, respectively. Pseudotyped viruses were generated by the cotransfection of $293 \mathrm{~T}$ cells with each of these expression vectors together with a pNL4-3RE-luciferase viral backbone plasmid. The capacity of the envelope to mediate viral entry was then tested by inoculating TZM-bl cells (approximately $1.5 \times 10^{4}$ cell/well) with the pseudotyped virus and measuring the luciferase activity (RLU) $48 \mathrm{~h}$ after infection. As shown in Figure 1, the majority of clones (45/52 from sample 20090121 and 30/43 from sample 20090720) were functional in terms of mediating viral entry, because their luciferase activity was similar to that of the positive control (CNE47). However, the positive clones differed in their entry efficiency, and seven from sample 20090121 and 13 from sample 20090720 failed to facilitate viral entry and their average luciferase activities were well below 1000 RLU (Figure 1).

\subsection{Two clusters of envelope sequences were identified in the patient's PBMC}

To study the genetic features of these functional clones $(45+30=75)$, we first conducted a sequencing analysis. Among the 45 clones from sample 20090121, 24 were unique, whereas among the 30 clones from sample 20090720, 12 were unique in terms of their nucleotide sequences. A phylogenetic analysis showed that these sequences fell into two major clusters: cluster 1 was closely related with the original CEN47 and CNE48, whereas cluster 2 was quite distant (Figure 2). The intracluster genetic distance was $0.019 \pm 0.003$ for cluster 1 and $0.005 \pm 0.001$ for cluster 2 , whereas the intercluster distance was $0.039 \pm 0.006$. Overall, cluster 1 was genetically more closely related to CNE47 and CNE48 $(0.034 \pm 0.005)$ than to cluster 2 $(0.042 \pm 0.007)$, suggesting that in evolutionary terms, the sequences in cluster 1 shared the same lineage with CNE47 and CNE48, whereas those in cluster 2 belonged to a relatively distant lineage.

Close examination of the phylogenetic tree revealed that all the sequences in cluster 1 were derived from sample 20090121, and all the sequences in cluster 2 were from sample 20090720. Because these two samples were collected only six months apart, their distinct sequence features suggest that the two clusters were probably evolving independently, although the original ancestor of both clusters is uncertain. It must be noted that because the full-length gp160 sequences were amplified directly from PBMC, without prior limiting dilution for single-genome amplification, the exact proportions and their fluctuations in the VRC01-resistant strains relative to the sensitive strains must be interpreted with caution. Furthermore, the sequences in both clusters were genetically more closely related to the prototype reference sequence 08.BC.CN.GX_6F than to any other sequence (Figure 2), consistent with our previous findings.

\subsection{Analysis of amino acid variations in the VRC01-binding domain}

Structural analysis of VRC01 bound to monomeric gp120 showed that it binds to the CD4bs, largely through loop D, the CD4-binding loop, the base of the V5 loop region, and $\beta 24$ [33]. To study the evolutionary changes in the amino acid residues in these regions, the full-length gp160 nucleotide sequences were translated into amino acid sequences and aligned with references HXB2, CNE47, and CNE48 (Figure 3). In the hypervariable regions, including V1, V2, $\mathrm{V} 3$, V4, and V5, significant differences were found between the sequences from samples 20090121 and 20090720, including both mutational variations and length polymorphisms. This finding supports the phylogenetic analysis, in which the sequences from the samples were separated largely because of these non-silent mutations in the hyper- 


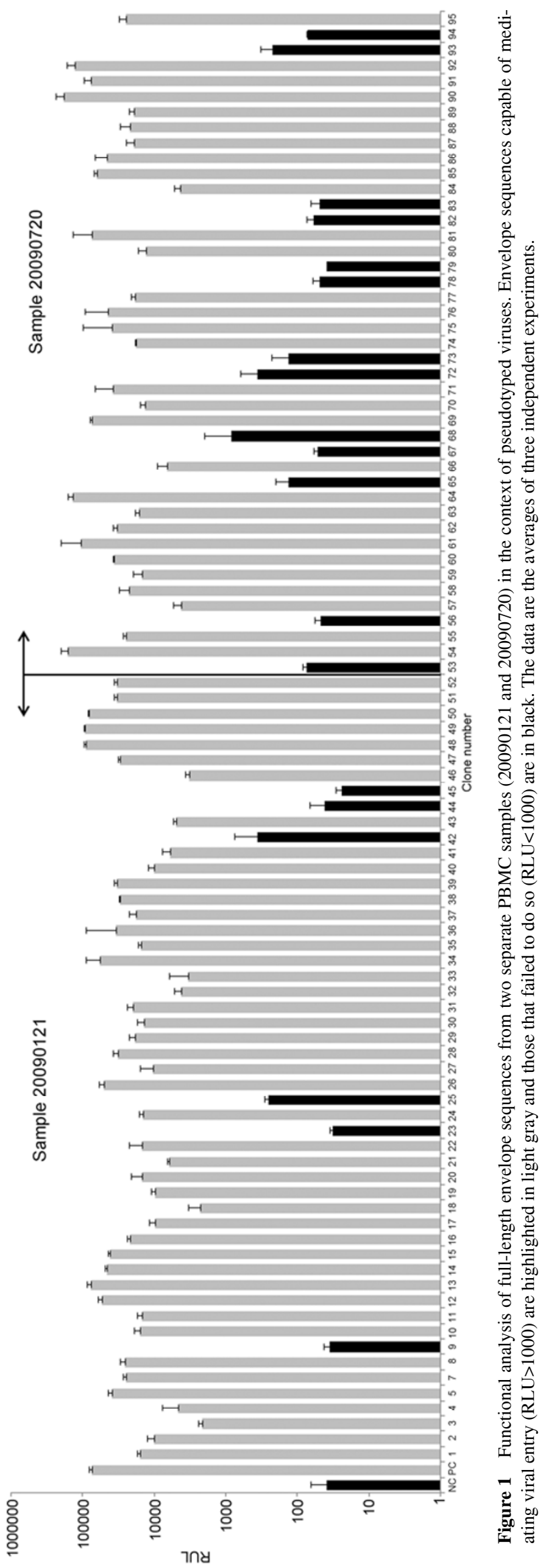




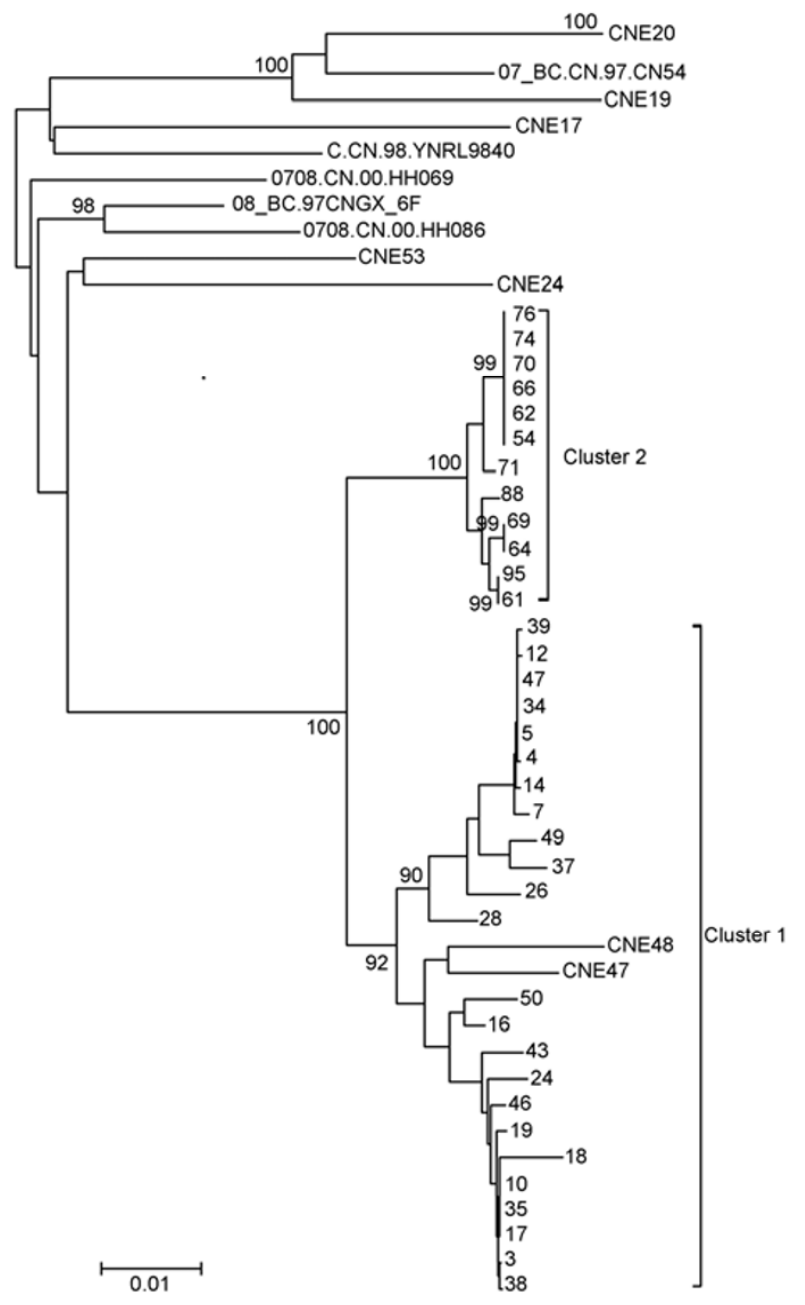

Figure 2 Unrooted neighbor-joining tree showing the genetic relationships among the full-length gp160 envelope clones. The horizontal branch lengths are drawn to scale so that the relatedness of different sequences can be readily assessed. Sequences in two clusters are indicated. A number of commonly used reference sequences for classifying HIV-1 subtypes and circulating recombinant forms and several previously characterized variants from China (CNE series) are included. The reliability of the branching order was tested by a bootstrap analysis of 1000 replications and those with $100 \%$ confidence are indicated [32].

variable regions. In contrast, loop D and the CD4-binding loop were extremely well conserved (Figure 3 ). This finding suggests that any changes in viral sensitivity to VRC01 are probably confined to residues within the V5 region rather than involving residues in the other VRC01-binding domains.

\subsection{Persistence of VRC01-resistant strains throughout the study period}

To study the viral sensitivity to VRC01 neutralization, we generated two representative pseudotyped viruses from the full-length gp160 genes from samples 20090121 and 20090720. These two gp160 genes (\#5 and \#61) were selected based on their unique V5 regions, because no sequence variations were found in loop D or the CD4-binding loop compared with the original CNE47 and CNE48 (Figure 3). As shown in Figure 4, the pseudotyped viruses built from the two envelopes were as resistant to VRC01 $\left(\mathrm{IC}_{50}=15.14 \mu \mathrm{g} \mathrm{mL}^{-1}\right.$ for $\# 5$ and $\mathrm{IC}_{50}=11.75 \mu \mathrm{g} \mathrm{mL}^{-1}$ for \#61) as CNE47 $\left(\mathrm{IC}_{50}=9.27 \mu \mathrm{g} \mathrm{mL}^{-1}\right.$ ) (Table 2). Like the original CNE47 and CNE48, both clones maintained their natural resistance to b12. However, all the pseudotyped viruses were sensitive to neutralization by Ibalizumab (Figure 4 , Table 2). Close examination of the V5 amino acid sequences revealed that both clones \#5 and \#61 contained a single asparagine residue at position 460 (N460), a potential PNGS, which we have previously shown is critical in conferring VRC01 resistance [29]. No other PNGSs were identified in the V5 region of the two clones, although two additional residues (Asn and Glu) were inserted into the V5 region of clone \#61 relative to that of \#5 (Figure 3, Table 2). Mutational changes from Gln to Lys and Thr at position 458 were found in clones \#5 and \#61, respectively, and from Thr to Ile at position 467 in clone \#61 compared with the original CNE47 sequence. None of these changes seems to have had any significant effect on viral sensitivity to VRC01, because neither \#5 nor \#61 differs dramatically from CNE47 in terms of their VRC01 sensitivity. Nevertheless, these results suggest that VRC01-resistant viruses persist and increase in their proportion of the infecting viruses in the peripheral blood, despite genetic mutations arising during antiretroviral therapy.

\section{Discussion}

In this study, we have characterized the evolutionary features of full-length gp160 from an HIV-1-infected individual

Table 2 Neutralization sensitivity to VRC01, b12, and ibalizumab

\begin{tabular}{|c|c|c|c|c|c|c|c|}
\hline \multirow{3}{*}{ Clone } & \multirow{3}{*}{$\begin{array}{c}\text { Sequence } \\
\text { V5/ } \beta 24 \\
(458-469)\end{array}$} & \multicolumn{6}{|c|}{ Neutralization } \\
\hline & & \multicolumn{2}{|c|}{ VRC01 } & \multicolumn{2}{|c|}{ b12 } & \multicolumn{2}{|c|}{ Ibalizumab } \\
\hline & & $\begin{array}{c}\mathrm{IC}_{50} \\
\left(\mu \mathrm{g} \mathrm{mL}^{-1}\right)\end{array}$ & $\begin{array}{c}\% \text { of } \\
\text { CNE47 }\end{array}$ & $\begin{array}{c}\mathrm{IC}_{50} \\
\left(\mu \mathrm{g} \mathrm{mL}^{-1}\right)\end{array}$ & $\begin{array}{c}\% \text { of } \\
\text { CNE47 }\end{array}$ & $\begin{array}{c}\mathrm{IC}_{50} \\
\left(\mu \mathrm{g} \mathrm{mL}^{-1}\right)\end{array}$ & $\begin{array}{c}\% \text { of } \\
\text { CNE47 }\end{array}$ \\
\hline CNE47 & GGQTNET-NNT-E TFR & 9.27 & 100 & $>50$ & 100 & 0.17 & 100 \\
\hline 5 & GGKTNET-NNT-E TFR & 15.14 & 163.32 & $>50$ & 100 & 0.09 & 52.94 \\
\hline 61 & GGTTNSTNNNTEEIFR & 11.75 & 126.75 & $>50$ & 100 & 0.17 & 100 \\
\hline
\end{tabular}




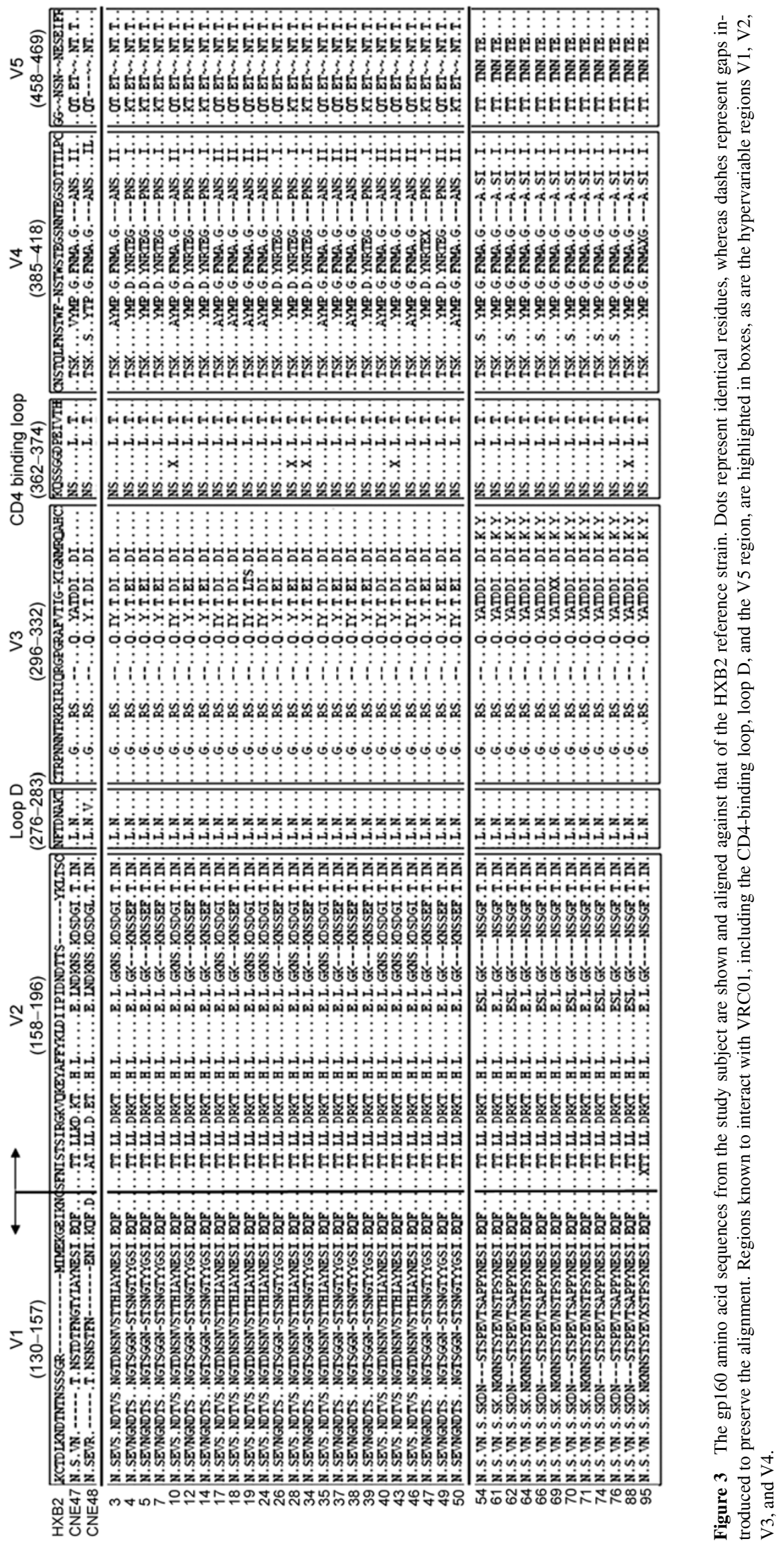



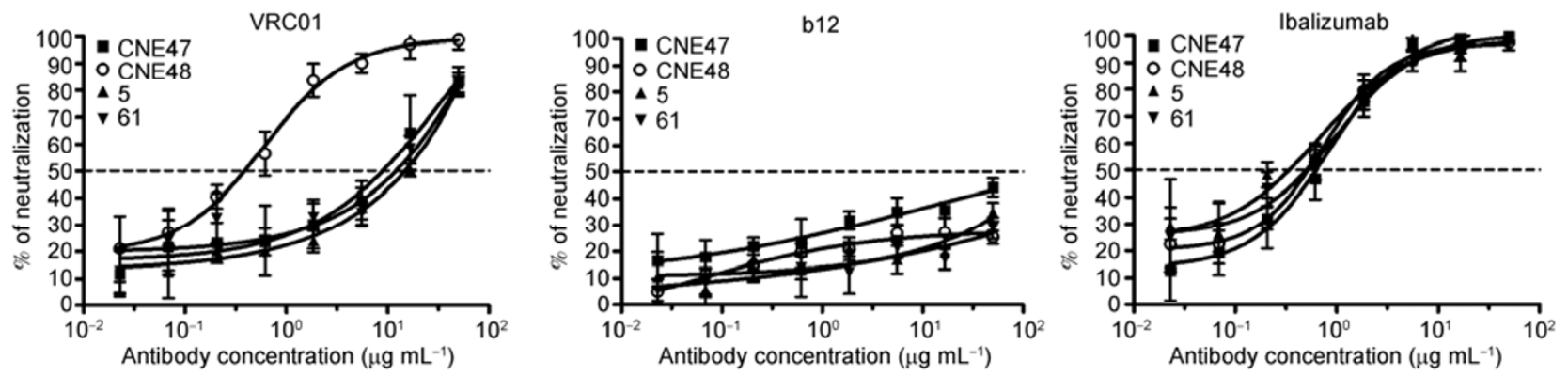

Figure 4 Comparison of representative envelope clones (\#5 and \#61) derived from mutant viruses with the original CNE47 and CNE48, in terms of their neutralization sensitivities to VRC01, b12, and ibalizumab. Both representative clones showed similar levels of resistance to VRC01 as CNE47. None of these mutations altered their sensitivity to b12 or ibalizumab neutralization.

whom we had previously shown to harbor VRC01-resistant strains. A genetic analysis identified significant changes in the hypervariable regions of gp160 during the study period, including both mutational variations and length polymorphisms. Phenotypic characterization of representative gp160 clones showed the persistence of the VRC01-resistant phenotype during the course of antiretroviral therapy. As in the original CNE47, the resistant phenotype was strongly associated with N460, a potential PNGS in the V5 region. The persistence and continuous evolution of VRC01-resistant HIV-1 in vivo will pose challenges to our future preventative and therapeutic interventions based on VRC01.

This is not the first report of VRC01-resistant strains of HIV-1. However, the mechanisms underlying the generation of these strains remain poorly understood, as do their evolutionary mechanisms in vivo. Although we have shown that N460 in the V5 region is critical for viral sensitivity to VRC01 in CRF08-BC-infected patients, we cannot exclude the possibility that other factors also confer resistance to VRC01. Further research is required to determine the impact of these V5 mutations on VRC01 sensitivity in a broader range of viral strains, especially viruses isolated from patients with VRC01-like neutralization activity. Furthermore, because many infected individuals do not show a detectable VRC01-like antibody response, many VRC01resistant viral variants are probably generated by random genetic mutations, and once they are generated, their persistence or turnover will be dependent on factors other than VRC01-like antibody responses. It is unlikely that their persistence in this individual was directly related to his antiretroviral therapy because the viral loads in the plasma were well suppressed and there was no rebound of resistant viruses. Alternatively, if a VRC01-like antibody response did exist at some period during infection, the generation and turnover of VRC01-resistant strains would then be largely dependent on the magnitude and duration of that response. In either case, the sheer presence and persistence of VRC01-resistant HIV-1 will pose tremendous challenges to anti-HIV-1 strategies based on VRC01. Strategies involving other bnmAbs, together with VRC01, will probably be more efficacious than those based on VRC01 alone.
Efforts are being made to develop novel immunogens and immunization strategies that can induce potent anti-CD4bs antibodies [34-40]. VRC01 remains one of the leading mAbs for HIV-1 prevention research and development, but the natural emergence of HIV-1 resistance has caused uncertainty about its broader use. Nonetheless, detailed analyses of VRC01 escape mechanisms and patterns of evolution increase our understanding of the interactions between the virus and the immune system in vivo, so that we can better target strategies to address treatment resistance. More studies are required to fully understand how the virus circumvents neutralization, particularly analyses of VRC01 sensitivity in a broader range of viral strains and their associated biological properties. Such research will undoubtedly optimize the development process and maximize the potential use of VRC01 in the clinical setting.

We are grateful to Dr. John Mascola of the Vaccine Research Center at the National Institutes of Health (NIH) for providing bnmAb VRCO1 and to Dr. David Ho at the Aaron Diamond AIDS Research Center for providing ibalizumab. We also thank Dr. Han XiaoXu for her assistance with the phylogenetic and genetic analysis. This work was supported by the National Grand Program on Key Infectious Disease Control (2012ZX10001-006, 2012ZX10001-009 and 2012ZX10001-003), the National Outstanding Youth Award (30825035), the National Natural Science Foundation of China (81101236), and the Tsinghua University Initiative Scientific Research Program.

1 Chan DC, Fass D, Berger JM, Kim PS. Core structure of gp41 from the HIV envelope glycoprotein. Cell, 1997, 89: 263-273

2 Weissenhorn W, Dessen A, Harrison SC, Skehel JJ, Wiley DC. Atomic structure of the ectodomain from HIV-1 gp41. Nature, 1997, 387: 426-430

3 Kwong PD, Wyatt R, Robinson J, Sweet RW, Sodroski J, Hendrickson WA. Structure of an HIV gp120 envelope glycoprotein in complex with the CD4 receptor and a neutralizing human antibody. Nature, 1998, 393: 648-659

4 Zhu P, Liu J, Bess J Jr., Chertova E, Lifson JD, Grise H, Ofek GA, Taylor KA, Roux KH. Distribution and three-dimensional structure of AIDS virus envelope spikes. Nature, 2006, 441: 847-852

5 Dalgleish A G, Beverley PC, Clapham PR, Crawford DH, Greaves MF, Weiss RA. The CD4 (T4) antigen is an essential component of the receptor for the AIDS retrovirus. Nature, 1984, 312: 763-767

6 Klatzmann D, Champagne E, Chamaret S, Gruest J, Guetard D, Hercend T, Gluckman JC, Montagnier L. T-lymphocyte T4 molecule 
behaves as the receptor for human retrovirus LAV. Nature, 1984, 312: $767-768$

7 Alkhatib G, Combadiere C, Broder CC, Feng Y, Kennedy PE, Murphy PM, Berger EA. CC CKR5: a RANTES, MIP-1alpha, MIP-1beta receptor as a fusion cofactor for macrophage-tropic HIV-1. Science, 1996, 272: 1955-1958

8 Deng H, Liu R, Ellmeier W, Choe S, Unutmaz D, Burkhart M, Di Marzio P, Marmon S, Sutton RE, Hill CM, Davis CB, Peiper SC, Schall TJ, Littman DR, Landau NR. Identification of a major co-receptor for primary isolates of HIV-1. Nature, 1996, 381: 661-666

9 Dragic T, Litwin V, Allaway GP, Martin SR, Huang Y, Nagashima KA, Cayanan C, Maddon PJ, Koup RA, Moore JP, Paxton WA. HIV- 1 entry into $\mathrm{CD} 4^{+}$cells is mediated by the chemokine receptor CC-CKR-5. Nature, 1996, 381: 667-673

10 Feng Y, Broder CC, Kennedy PE, Berger EA. HIV-1 entry cofactor: functional cDNA cloning of a seven-transmembrane, $G$ protein-coupled receptor. Science, 1996, 272: 872-877

11 Zhang L, Huang Y, He T, Cao Y, Ho DD. HIV-1 subtype and second-receptor use. Nature, 1996, 383: 768

12 Scheid JF, Mouquet H, Feldhahn N, Seaman MS, Velinzon K, Pietzsch J, Ott RG, Anthony RM, Zebroski H, Hurley A, Phogat A, Chakrabarti B, Li Y, Connors M, Pereyra F, Walker BD, Wardemann H, Ho D, Wyatt RT, Mascola JR, Ravetch JV, Nussenzweig MC. Broad diversity of neutralizing antibodies isolated from memory B cells in HIV-infected individuals. Nature, 2009, 458: 636-640

13 Wu X, Yang ZY, Li Y, Hogerkorp CM, Schief WR, Seaman MS, Zhou T, Schmidt SD, Wu L, Xu L, Longo NS, McKee K, O'Dell S, Louder MK, Wycuff DL, Feng Y, Nason M, Doria-Rose N, Connors M, Kwong PD, Roederer M, Wyatt RT, Nabel GJ, Mascola JR. Rational design of envelope identifies broadly neutralizing human monoclonal antibodies to HIV-1. Science, 2010, 329: 856-861

14 Diskin R, Scheid JF, Marcovecchio PM, West AP Jr., Klein F, Gao H, Gnanapragasam PN, Abadir A, Seaman MS, Nussenzweig MC, Bjorkman PJ. Increasing the potency and breadth of an HIV antibody by using structure-based rational design. Science, 2011, 334: 1289-1293

15 Scheid JF, Mouquet H, Ueberheide B, Diskin R, Klein F, Oliveira TY, Pietzsch J, Fenyo D, Abadir A, Velinzon K, Hurley A, Myung S, Boulad F, Poignard P, Burton DR, Pereyra F, Ho DD, Walker BD, Seaman MS, Bjorkman PJ, Chait BT, Nussenzweig MC. Sequence and structural convergence of broad and potent HIV antibodies that mimic CD4 binding. Science, 2011, 333: 1633-1637

16 Walker LM, Huber M, Doores KJ, Falkowska E, Pejchal R, Julien JP, Wang SK, Ramos A, Chan-Hui PY, Moyle M, Mitcham JL, Hammond PW, Olsen OA, Phung P, Fling S, Wong $\mathrm{CH}$, Phogat $\mathrm{S}$, Wrin T, Simek MD, Koff WC, Wilson IA, Burton DR, Poignard P. Broad neutralization coverage of HIV by multiple highly potent antibodies. Nature, 2011, 477: 466-470

17 Georgiev IS, Gordon Joyce M, Zhou T, Kwong PD. Elicitation of HIV-1-neutralizing antibodies against the CD4-binding site. Curr Opin HIV AIDS, 2013, 8: 382-391

18 Liao HX, Lynch R, Zhou T, Gao F, Alam SM, Boyd SD, Fire AZ, Roskin KM, Schramm CA, Zhang Z, Zhu J, Shapiro L, Mullikin JC, Gnanakaran S, Hraber P, Wiehe K, Kelsoe G, Yang G, Xia SM, Montefiori DC, Parks R, Lloyd KE, Scearce RM, Soderberg KA, Cohen M, Kamanga G, Louder MK, Tran LM, Chen Y, Cai F, Chen S, Moquin S, Du X, Joyce MG, Srivatsan S, Zhang B, Zheng A, Shaw GM, Hahn BH, Kepler TB, Korber BT, Kwong PD, Mascola JR, Haynes BF. Co-evolution of a broadly neutralizing HIV-1 antibody and founder virus. Nature, 2013, 496: 469-476

19 Zhou T, Zhu J, Wu X, Moquin S, Zhang B, Acharya P, Georgiev IS, Altae-Tran HR, Chuang GY, Joyce MG, Do Kwon Y, Longo NS, Louder MK, Luongo T, McKee K, Schramm CA, Skinner J, Yang Y, Yang Z, Zhang Z, Zheng A, Bonsignori M, Haynes BF, Scheid JF, Nussenzweig MC, Simek M, Burton DR, Koff WC, Mullikin JC, Connors M, Shapiro L, Nabel GJ, Mascola JR, Kwong PD. Multidonor analysis reveals structural elements, genetic determinants, and maturation pathway for HIV-1 neutralization by VRC01-class anti- bodies. Immunity, 2013, 39: 245-258

20 Walker LM, Phogat SK, Chan-Hui PY, Wagner D, Phung P, Goss JL, Wrin T, Simek MD, Fling S, Mitcham JL, Lehrman JK, Priddy FH, Olsen OA, Frey SM, Hammond PW, Kaminsky S, Zamb T, Moyle M, Koff WC, Poignard P, Burton DR. Broad and potent neutralizing antibodies from an African donor reveal a new HIV-1 vaccine target. Science, 2009, 326: 285-289

21 Wu X, Zhou T, Zhu J, Zhang B, Georgiev I, Wang C, Chen X, Longo NS, Louder M, McKee K, O'Dell S, Perfetto S, Schmidt SD, Shi W, Wu L, Yang Y, Yang ZY, Yang Z, Zhang Z, Bonsignori M, Crump JA, Kapiga SH, Sam NE, Haynes BF, Simek M, Burton DR, Koff WC, Doria-Rose NA, Connors M, Mullikin JC, Nabel GJ, Roederer M, Shapiro L, Kwong PD, Mascola JR. Focused evolution of HIV-1 neutralizing antibodies revealed by structures and deep sequencing. Science, 2011, 333: 1593-1602

22 West AP Jr., Diskin R, Nussenzweig MC, Bjorkman PJ. Structural basis for germ-line gene usage of a potent class of antibodies targeting the CD4-binding site of HIV-1 gp120. Proc Natl Acad Sci USA, 2012, 109: E2083-2090

23 Falkowska E, Ramos A, Feng Y, Zhou T, Moquin S, Walker LM, Wu X, Seaman MS, Wrin T, Kwong PD, Wyatt RT, Mascola JR, Poignard P, Burton DR. PGV04, an HIV-1 gp120 CD4 binding site antibody, is broad and potent in neutralization but does not induce conformational changes characteristic of CD4. J Virol, 2012, 86: 4394-4403

24 Corti D, Langedijk JP, Hinz A, Seaman MS, Vanzetta F, Fernandez-Rodriguez BM, Silacci C, Pinna D, Jarrossay D, Balla-Jhagjhoorsingh S, Willems B, Zekveld MJ, Dreja H, O'Sullivan E, Pade C, Orkin C, Jeffs SA, Montefiori DC, Davis D, Weissenhorn W, McKnight A, Heeney JL, Sallusto F, Sattentau QJ, Weiss RA, Lanzavecchia A. Analysis of memory B cell responses and isolation of novel monoclonal antibodies with neutralizing breadth from HIV-1-infected individuals. PLoS ONE, 2010, 5: e8805

25 Walker LM, Simek MD, Priddy F, Gach JS, Wagner D, Zwick MB, Phogat SK, Poignard P, Burton DR. A limited number of antibody specificities mediate broad and potent serum neutralization in selected HIV-1 infected individuals. PLoS Pathog, 2010, 6: e1001028

26 Wu X, Zhou T, O'Dell S, Wyatt RT, Kwong PD, Mascola JR. Mechanism of human immunodeficiency virus type 1 resistance to monoclonal antibody B12 that effectively targets the site of CD4 attachment. J Virol, 2009, 83: 10892-10907

27 Wu X, Wang C, O'Dell S, Li Y, Keele BF, Yang Z, Imamichi H, Doria-Rose N, Hoxie JA, Connors M, Shaw GM, Wyatt RT, Mascola JR. Selection pressure on HIV-1 envelope by broadly neutralizing antibodies to the conserved CD4-binding site. J Virol, 2012, 86: 5844-5856

28 Shang H, Han X, Shi X, Zuo T, Goldin M, Chen D, Han B, Sun W, Wu H, Wang X, Zhang L. Genetic and neutralization sensitivity of diverse HIV-1 env clones from chronically infected patients in China. J Biol Chem, 2011, 286: 14531-14541

29 Guo D, Shi X, Arledge KC, Song D, Jiang L, Fu L, Gong X, Zhang S, Wang X, Zhang L. A single residue within the V5 region of HIV-1 envelope facilitates viral escape from the broadly neutralizing monoclonal antibody VRC01. J Biol Chem, 2012, 287: 43170-43179

30 Larkin MA, Blackshields G, Brown NP, Chenna R, McGettigan PA, McWilliam H, Valentin F, Wallace IM, Wilm A, Lopez R, Thompson JD, Gibson TJ, Higgins DG. Clustal W and Clustal X version 2.0. Bioinformatics, 2007, 23: 2947-2948

31 Tamura K, Peterson D, Peterson N, Stecher G, Nei M, Kumar S. MEGA5: molecular evolutionary genetics analysis using maximum likelihood, evolutionary distance, and maximum parsimony methods. Mol Biol Evol, 2011, 28: 2731-2739

32 Felsenstein J. Phylogenies from molecular sequences: inference and reliability. Annu Rev Genet, 1988, 22: 521-565

33 Zhou T, Georgiev I, Wu X, Yang ZY, Dai K, Finzi A, Kwon YD, Scheid JF, Shi W, Xu L, Yang Y, Zhu J, Nussenzweig MC, Sodroski J, Shapiro L, Nabel GJ, Mascola JR, Kwong PD. Structural basis for broad and potent neutralization of HIV-1 by antibody VRC01. Sci- 
ence, 2010, 329: 811-817

34 Dey B, Pancera M, Svehla K, Shu Y, Xiang SH, Vainshtein J, Li Y, Sodroski J, Kwong PD, Mascola JR, Wyatt R. Characterization of human immunodeficiency virus type 1 monomeric and trimeric gp120 glycoproteins stabilized in the CD4-bound state: antigenicity, biophysics, and immunogenicity. J Virol, 2007, 81: 5579-5593

35 Douagi I, Forsell MN, Sundling C, O’Dell S, Feng Y, Dosenovic P, Li Y, Seder R, Lore K, Mascola JR, Wyatt RT, KarlssonHedestam GB. Influence of novel CD4 binding-defective HIV-1 envelope glycoprotein immunogens on neutralizing antibody and $\mathrm{T}$-cell responses in nonhuman primates. J Virol, 2009, 84: 1683-1695

36 Feng Y, McKee K, Tran K, O’Dell S, Schmidt SD, Phogat A, Forsell MN, KarlssonHedestam GB, Mascola JR, Wyatt RT. Biochemically defined HIV-1 envelope glycoprotein variant immunogens display differential binding and neutralizing specificities to the CD4-binding site. J Biol Chem, 2011, 287: 5673-5686

37 Koch M, Pancera M, Kwong PD, Kolchinsky P, Grundner C, Wang L,
Hendrickson WA, Sodroski J, Wyatt R. Structure-based, targeted deglycosylation of HIV-1 gp120 and effects on neutralization sensitivity and antibody recognition. Virology, 2003, 313: 387-400

38 Li Y, Svehla K, Mathy NL, Voss G, Mascola JR, Wyatt R. Characterization of antibody responses elicited by human immunodeficiency virus type 1 primary isolate trimeric and monomeric envelope glycoproteins in selected adjuvants. J Virol, 2006, 80: 1414-1426

39 Pancera M, Lebowitz J, Schon A, Zhu P, Freire E, Kwong PD, Roux $\mathrm{KH}$, Sodroski J, Wyatt R. Soluble mimetics of human immunodeficiency virus type 1 viral spikes produced by replacement of the native trimerization domain with a heterologous trimerization motif: characterization and ligand binding analysis. J Virol, 2005, 79: 9954-9969

40 Saha P, Bhattacharyya S, Kesavardhana S, Miranda ER, Ali PS, Sharma D, Varadarajan R. Designed cyclic permutants of HIV-1 gp120: implications for envelope trimer structure and immunogen design. Biochemistry, 2012, 51: 1836-1847

Open Access This article is distributed under the terms of the Creative Commons Attribution License which permits any use, distribution, and reproduction in any medium, provided the original author(s) and source are credited. 